\section{Coronavirus Disease (COVID-19) in Children: Indian Perspectives}

Balasubramanian, et al. [1] have concisely described various aspects related to coronavirus disease (COVID19 ) in children in the Indian setting. We would like to address additional issues related to epidemiology of COVID-19, reasons for uneventful clinical course in children, and the contributions of Indian judiciary to the health of children during the pandemic.

From the point of epidemiology, reporting and testing of children for COVID-19 are less, which lead to undersampling and under-reporting of the disease [2]. Decreased illness severity and an overall resilience to this disease in children facilitate transmission of the organism by rendering children as carriers. Moreover, children can shed COVID-19 virus through stools for a longer time. This is attributed to increased viral load through the act of swallowing the virus containing sputum or saliva [3] and the expression of angiotensin converting enzyme 2 (ACE2) in the intestine.

From a physiological perspective, a higher frequency of beating lung cilia [4] in children hinders the virus entry into lung pneumocytes. Apart from that, they have low risk for COVID-19 associated acute respiratory distress syndrome (ARDS) due to decreased generation of thrombin, and fibrin formation [5,6]. The other reasons for the protection of lungs and airways are lack of comorbidities and less exposure to particulate matter and pollutants [7], as also mentioned by Balasubramanian, et al. [1]. In addition, increased expression of ACE2 in pediatric lungs and other tissues gives additional protection and contributes to uneventful clinical course [4]. Moreover, they escape from cytokine storm $[6,8]$ and hence, fatal complications are rarely observed $[8,9]$. In addition, exposure of pediatric population to various vaccines [10] carried out as per the Universal immunization program in India enhance the activation of the immune system $[11,12]$, and contribute to uneventful clinical course. Further, we think that the relative lack of physical and mental stress in children likely gives additional protection via psychoneuroimmunology.

Understanding the gravity of the current and emerging situations of COVID-19, the Supreme Court of India has given directions [13] and measures to Child Welfare Committee, Juvenile Justice Boards, Children's courts, Child Care Institutions and State Governments across India towards the care and attention of children in conflict with law and those kept in various types of homes including those under foster and kinship care. Thus, Indian judiciary is the first in the globe to look into the needs of marginalized children and give specific directions for their care in this pandemic.

Over all, we believe that Indian children will withstand the outbreak of the novel coronavirus pandemic, but may be a link in transmission due to possibility of underreporting of cases, sub-clinical syndrome and longer shedding period of virus. We have to urgently address these through effective public health approach, including possible vaccination against COVID-19, as and when available [14].

Funding: None; Competing Interests: None stated.

Published online: April 26, 2020; PII: S097475591600167

\section{SUbRAMANIAN SENTHILKUMARAN ${ }^{1}$, RAMACHANDRAN MEENAKSHISUNDARAM ${ }^{1}$, SWENI SHAH ${ }^{2 *}$ AND Ponniah Thirumalaikolundusubramanian ${ }^{3}$ From ${ }^{1}$ Department of Emergency and Critical Care, Manian Medical Centre, Erode, India; ${ }^{2}$ Royal Free NHS Foundation Trust, London, United Kingdom; and ${ }^{3}$ Trichy SRM Medical College Hospital and Research Centre, Irungalur, Tiruchirapalli, India. *sweni.shah@nhs.net}

\section{REFERENCES}

1. Balasubramanian S, Rao NM, Goenka A, Roderick M, Ramanan AV. Coronavirus disease (covid-19) in children what we know so far and what we do not. Indian Pediatr. 2020 Apr 9. Available from: https://www. indian pediatrics.net/CONVID29.03.2020/SA-00159.pdf. Accessed April 22, 2020.

2. Dong Y, Mo X, Hu Y, Qi X, Jiang F, Jiang Z, et al. Epidemiological characteristics of 2143 pediatric patients with 2019 coronavirus disease in China. Pediatrics. 2020. Available from: https://pediatrics.aappublications.org/ content/ pediatrics/early/2020/ 03/16/peds.20200702.full.pdf. Accessed April 19, 2020.

3. Ma X, Su L, Zhang Y, Zhang X, Gai Z, Zhang Z. Do children need a longer time to shed SARS-CoV-2 in stool than adults? J Microbiol Immunol Infect. 2020. Available from: https://www.sciencedirect.com/science/article/pii/ S1684118220300700. Accessed April 18, 2020.

4. Chilvers MA, Rutman A, O'Callaghan C. Functional analysis of cilia and ciliated epithelial ultrastructure in healthy children and young adults. Thorax. 2003;58:333-8.

5. Moore HB, Moore EE, McIntyre RC, Moore PK, Talmor $\mathrm{DS}$, Moore FA, et al. Is there a role for tissue plasminogen activator (tPA) as a novel treatment for refractory COVID19 associated acute respiratory distress syndrome (ARDS)? J Trauma Acute Care Surg. 2020. Available from: https://journals.lww.com/jtrauma/Citation/9000/Is_There_ a_Role_for_Tissue_Plasminogen_Activator.97967.aspx. Accessed April 18, 2020. 
6. Ignjatovic V, Pelkmans L, Kelchtermans H, Al Dieri R, Hemker C, Kremers R, et al. Differences in the mechanism of blood clot formation and nanostructure in infants and children compared with adults. Thromb Res. 2015;136:1303-9.

7. Yang J, Chen Y, Yu Z, Ding H, Ma Z. The influence of PM2.5 on lung injury and cytokines in mice. Exp Ther Med. 2019;18:2503-11.

8. Ng PC, Lam CW, Li AM, Wong CK, Cheng FW, Leung TF, et al. Inflammatory cytokine profile in children with severe acute respiratory syndrome. Pediatrics. 2004;113:e7-14.

9. Liniger M, Zuniga A, Tamin A, Azzouz-Morin TN, Knuchel M, Marty RR, et al. Induction of neutralising antibodies and cellular immune responses against SARS coronavirus by recombinant measles viruses. Vaccine. 2008;26:2164-74.

10. Prompetchara E, Ketloy C, Palaga T. Immune responses in COVID-19 and potential vaccines: Lessons learned from
SARS and MERS epidemic. Asian Pac J Allergy Immunol. 2020;38:1-9.

11. Ruf BR, Knuf M. The burden of seasonal and pandemic influenza in infants and children. Eur $\mathrm{J}$ Pediatr. 2014;173:265-76.

12. Benn CS, Netea MG, Selin LK, Aaby P. A small jab - A big effect: Nonspecific immunomodulation by vaccines. Trends Immunol. 2013;34:431-9.

13. Bureau IL. India Legal Bureau. Supreme court issues directions for prevention of children from Covid-19. 2020. Available from: https://www.indialegallive.com/ constitutional-law-news/supreme-court-news/supremecourt-issues-directions-prevention-children-covid-1994696. Accessed April 18, 2020.

14. Ella KM, Krishna Mohan V. Coronavirus vaccines: Light at the end of the tunnel. Available from: https:// www.indianpediatrics.net/CONVID29.03.2020/PERS00163. pdf. Accessed April 24, 2020.

\section{Does a Crying Child Enhance the Risk for COVID-19 Transmission?}

The pandemic of coronavirus disease (COVID-19) has led all of us to recalibrate both our personal and professional life [1]. In our routine pediatric outpatient practice for non-COVID cases i.e. well baby visits and kids presenting with afebrile, non-respiratory symptoms, a surgical face mask with proper hand hygiene and gloves has been recommended for health care professionals [2]. However, for those handling aerosol-generating procedures (AGP), respirators and additional personal protection equipment (PPE) are recommended [3]. Aerosol is defined as suspension of fine solid particles or liquid droplets in air or another gas. Aerosols of varying severity are generated on sneezing, coughing, talking and also during normal breathing [4]. AGPs are believed to produce aerosols and droplets as source of respiratory pathogens that exposes the health care workers to pathogens causing acute respiratory infections including Severe acute respiratory syndrome Coronavirus 2 (SARS-CoV-2) [5]. AGPs are generated on performing certain medical procedures like intubation, manual ventilation, non-invasive ventilation, tracheostomy insertion etc. on infected cases. However, it is not clear if the risk is due to direct airborne transmission or secondary exposure to respiratory droplets.

It is established that even loud speaking results in increased aerosol generation i.e. aerosol super-emission
[6]. Extrapolating the same logic even a crying and screaming child should produce aerosol super-emission. Although an operational definition for AGP is in place, the relation to crying and its possible effects of increased aerosol generation has so far not been stressed.

In a pandemic situation, we need to ponder on some points: even infants and toddlers who come for routine vaccinations or non-respiratory complaints can be asymptomatic carriers or in pre-symptomatic period of transmission; implementing source control measures like face mask and social distancing in this age group practically difficult; crying, a common occurrence in this age group, also increases the risk of aerosol generation and transmission; and, proximity of these kids to caregivers and their attenders along with sustained crying either due to anxiety or fear might further increase the risk and load of aerosol.

In view of the yet unknown increased risks posed by expected or unexpected crying of asymptomatic children in the transmission of COVID-19, it may be prudent to make every effort to avoid examining a crying child without adequate precautions.

Funding: None; Competing Interest: None stated. Published online: April 26, 2020; PII: S097475591600166

$$
\begin{array}{r}
\text { SoMU SIVABALAN }{ }^{1} \text { AND MV SRINATH }{ }^{2 *} \\
{ }^{1} \text { Department of Pediatrics, Kanchi Kamakoti CHILDS Trust } \\
\text { Hospital, } \\
\text { Nungambakkam, Chennai; and }{ }^{2} \text { Department of Pediatrics, } \\
\text { Saveetha Medical College and Hospital, Thandalam, } \\
\text { Kancheepuram; Tamil Nadu, India. } \\
* d r m v \text {mmc@yahoo.com }
\end{array}
$$

